Article

\title{
Perspectivism Narrow and Wide: An Examination of Nietzsche's Limited Perspectivism from a Daoist Lens
}

Casey Rentmeester

\begin{abstract}
Western liberal intellectuals often find themselves in a precarious situation with regard to whether or not they should celebrate and endorse Friedrich Nietzsche as a philosopher who we should all unequivocally embrace into our Western philosophical canon. While his critique of the Western philosophical tradition and his own creative insights are unprecedented and immensely important, his blatant inegalitarianism and remarks against women are often too difficult to stomach. This paper attempts to introduce Western philosophers to Chuang Tzu, a Chinese thinker who shares much of Nietzsche's style and philosophy, but also espouses a thoroughgoing egalitarianism. It does so by comparing Nietzsche and Chuang Tzu in regard to their methods, style, and philosophical beliefs, with a particular emphasis on the naturalism and perspectivism found in each thinker's philosophy. The hope is to provide Western liberal-minded intellectuals interested in Nietzsche and in equality with another perspective to bolster their thinking.
\end{abstract}

Keywords: Chuang Tzu, Nietzsche, naturalism, egalitarianism

\section{Introduction}

$\mathrm{W}$

estern readers often find Nietzsche to be a breath of fresh air. Whereas much of the Western philosophical tradition is pervaded by an emphasis on clear, concise, logical argumentation that is consistent and unambiguous, Nietzsche writes with a style that is more akin to a poet. He unabashedly writes in verse, utilizes metaphors, engages in polemics, employs sarcasm, mocks his predecessors and contemporaries, uses aphorisms, and even occasionally bursts into song. His willingness to venture outside of the traditional Western styles of philosophizing that emphasize reason and rationality shows that he is not afraid to write from his heart as well as his head. In this regard, his way of philosophizing is more similar to thinkers in the Eastern tradition. In China, for

(c) 2013 Casey Rentmeester http://www.kritike.org/journal/issue 12/rentmeester june2013.pdf ISSN 1908-7330 


\section{PERSPECTIVISM NARROW AND WIDE}

instance, philosophers are said to philosophize with their xin, which is commonly translated into English as "heart-mind" in order to stress that ideas come from both the soul and the intellect for Chinese thinkers. ${ }^{1}$ Nietzsche once remarked, "I must learn to think more orientally about philosophy and knowledge" ${ }^{2}$ and, in many ways, he accomplished this task by not only departing from the traditional style of Western philosophizing but also questioning the basic elements of the Western metaphysical tradition. Nietzsche puts into question the so-called "givens" of Western metaphysics such as the existence of subjects, substances, free will, and even fixed things. All of these traditional elements of Western philosophy are absent in the Eastern tradition, and in many ways, Nietzsche's ability to break free from the common Western philosophical mold allows him to attain a view of the world that approximates many elements of Eastern thought. Therefore, despite the fact that he comes from the Western tradition, he can be seen as "Eastern" in many regards.

Perhaps these Eastern aspects of Nietzsche's philosophy will allow us to expand our conception of philosophy to include worldviews that do not fall within the Western tradition. I will argue that Nietzsche's philosophy provides a bridge for at least one non-Western perspective: that of philosophical Daoism. In doing so, I will compare Nietzsche's philosophy with the Daoist philosopher, Chuang Tzu. Nietzsche and Chuang Tzu are similar in both their philosophical styles and their ways of looking at the world. They each utilize metaphors, mock the conservative elements of their respective traditions, and understand the power of narratives and aphorisms. In regard to their philosophical doctrines, they each espouse perspectivism, view the self as a constantly processual entity composed of multiple drives, see the world as dynamic forces of energy, and subscribe to a sort of naturalism. For the purposes of this paper, we will focus on the naturalism one finds in both Nietzsche and Chuang Tzu where "naturalism" can be defined as the idea that human beings should live in accordance with life's natural processes. One of the consequences of Nietzsche's naturalism is his inegalitarianism and his endorsing of the strong overpowering the weak. Chuang Tzu's naturalism, on the other hand, leads him to a thoroughgoing egalitarianism and respect for others. Juxtaposing Nietzsche with Chuang Tzu may not only shed some light on the similarities between the two thinkers, but it may also provide Western liberalminded intellectuals interested in Nietzsche and in equality with another perspective to bolster their thinking.

\footnotetext{
${ }^{1}$ In fact, Chinese do not make a distinction between the two. For a more detailed analysis of xin, see Roger Ames and David's Hall's commentary in Daodejing: "Making This Life Significant": A Philosophical Translation, trans. Roger Ames and David Hall (New York: Ballantine Books, 2003), 25-6 and 38-9.

2 This is an unpublished note from 1884. Cf. Friedrich Nietzsche: Sämtliche Werke, Kritische Studienausgabe, ed. Giorgio Colli and Mazzino Montinari (Berlin and New York: de Gruyter, 1967-1977), volume 11, 26.
}

(C) 2013 Casey Rentmeester http://www.kritike.org/journal/issue 12/rentmeester june2013.pdf ISSN 1908-7330 


\section{The World as Dynamic Forces of Energy}

Before we can examine the naturalism one finds in Nietzsche and Chuang Tzu and the implications it has on their views on equality, we must understand how Nietzsche and Chuang Tzu view reality. Perhaps the best way to start off in this endeavor is to state explicitly how both philosophers' views of reality differ from most thinkers in the Western tradition. The common thread that has characterized Western metaphysics is the view that reality is essentially "enduring presence." This view stems from Plato, who argued that although the world of appearance is one of change, the true reality is the transcendent reality of the Forms, which are permanent and unchanging. Since Plato, Western philosophers have tried to retain the idea that what is "really real"3 is something that is enduring and constant. The fundamental building blocks of reality are generally seen as substances, which we can define as reliably stable things that endure over time. These substances are said to interact with one another through causal "push and pull" relations, which work in lawful manners.

One of Nietzsche's major projects is to overcome this metaphysics of enduring presence and posit a view of reality that is more dynamic and organic. Instead of adopting the Platonic view that privileges the world of Forms over the world of appearance, Nietzsche rises above this dualism altogether by saying that the world is essentially dynamic quanta that interact with one another. ${ }^{4}$ Nietzsche believes that "the fundamental faith of the metaphysicians is the faith in opposite values" $^{5}$ such as reality and appearance. However, this faith is unwarranted. $\mathrm{He}$ states that "we have no categories at all that permit us to distinguish a "world in itself from a 'world of appearance""6 and, therefore, this distinction needs to be abandoned. Nietzsche's attempt at overcoming this dualistic framework comes about through his idea of the will to power. He states, "This world is the will to power-and nothing besides! And you yourselves are also this will to power-and nothing besides!"7 Here, it may seem as though Nietzsche is replacing a dualistic view of reality with a monistic one. However, this simple interpretation is potentially misleading. For Nietzsche, the will to power is not a singularity; rather, it should be seen as a multiplicity of dynamic forces of energy that simultaneously

${ }^{3}$ This is a phrase used by Wilfrid Sellars to denote the world as it is in itself. See his Science, Perception and Reality (London: Routledge \& Kegan Paul Ltd., 1963).

${ }^{4}$ Nietzsche speaks of the world as dynamic quanta in The Will to Power, trans. Walter Kaufmann and R.J. Hollingdale and ed. Walter Kaufmann (New York: Random House, Inc., 1967), 635. All citations to Nietzsche's works refer to the section rather than the page to allow for crossreferencing alternative translations.

${ }^{5}$ Friedrich Nietzsche, Beyond Good and Evil: Prelude to a Philosophy of the Future, trans. Walter Kaufmann (New York: Random House, Inc., 1966), 2.

${ }^{6}$ Nietzsche, Will to Power, 488.

${ }^{7}$ Ibid., 1067. 
strive to overcome each other and thereby increase in power. The Nietzschean world is a complex interplay of active, energetic processes that cannot be subsumed into any simple dualistic framework (or any other reductive framework, for that matter).

One essential aspect of Nietzsche's view of reality is that there is nothing compelling the different forces of energy to strive as they do. There is no transcendent God over and above the world that makes it flow as it does. In fact, in Nietzsche's theory of the world as will to power, there are not even subjects who intentionally will to enhance their power. Not only does he think that the idea of willing in the psychological sense of intentionally trying to bring about a state of affairs is merely a "popular prejudice," he also thinks that "the 'subject' is only a fiction," which means that we should not view the "will" in the will to power as something that is intended by an individual. Rather, for Nietzsche, "there is no 'being' behind doing, effecting, becoming; 'the doer' is merely a fiction added to the deed-the deed is everything." ${ }^{10}$ The world consists of a dynamic interplay of drives that are not intended by anyone in particular. This view of reality includes all aspects of the world, including the putatively self-willed drives that guide human action. Indeed, Nietzsche's explicit inclusion of human beings as "will to power and nothing besides" shows that he views human beings and the world as continuous. The will to power just is the strivings of dynamic quanta of energy, and there is no autonomous subject responsible for these strivings-even when it comes to the strivings of human beings. Therefore, instead of thinking of the will to power as a process that is acted out by individuals or governed by a transcendent deity, we should think of it as something that spontaneously occurs just by virtue of the way the world is constituted.

Chuang Tzu's view of reality is similar to Nietzsche's in that he does not view reality as a conglomeration of substances. However, while Nietzsche is at pains to convince his Western readers that the notion of substance is problematic, Chuang Tzu has the advantage of writing in the East where he can take the idea of the world as a dynamic flow of energy to be a given assumption. Eastern worldviews in general, and Daoist worldviews in particular, view reality as processual and active rather than as unchanging and static. Roger Ames and David Hall describe Daoist cosmology as follows:

The Daoist does not posit the existence of some permanent reality behind appearances, some unchanging substratum, some essential defining aspect behind the accidents of

\footnotetext{
${ }^{8}$ Nietzsche, Beyond Good and Evil, 19.

${ }^{9}$ Nietzsche, Will to Power, 370.

${ }^{10}$ Friedrich Nietzsche, On the Geneology of Morals, in Basic Writings of Nietzsche, trans. and ed. by Walter Kaufmann (New York: Random House, Inc., 1967), 13.

(c) 2013 Casey Rentmeester http://www.kritike.org/journal/issue_12/rentmeester june2013.pdf ISSN 1908-7330 
change. Rather, there is just the ceaseless and usually cadenced flow of experience. ${ }^{11}$

For Daoists, nature is seen as a continual and spontaneous flow of energy. And, just as Nietzsche thinks that there is no transcendent deity guiding the various flows of energy that occur in nature, Daoists also refuse to posit any sort of "cosmic choreographer."12 This is evidenced by Chuang Tzu's metaphor of the pipes of heaven. In the book of Chuang $T z u$, an interlocutor asks what is behind the processes of nature (i.e., the pipes of heaven) and the Daoist sage responds that things simply flow spontaneously by their own unique constitutions:

[The interlocutor asks,] "... Let me ask about the pipes of Heaven. Who is it that puffs out the myriads which are never the same, who in their self-ending is sealing them up, in their self-choosing is impelling the force into them?"13 [The sage responds,] "As for the pipes of heaven,...the myriad sounds produced by the blowing of the wind are different, yet all it does is elicit the natural propensities of the hollows themselves. What need is there for something else to stimulate them?"14

Before we can flesh out the meaning of this passage, a few notes of clarification are in order. First of all, the pipes of heaven should be understood on a naturalistic rather than supernatural level. In the West, we tend to equate "heaven" with a transcendent reality due to our Judeo-Christian background. However, Chuang Tzu is not speaking of anything otherworldly in this passage. The word commonly translated as "heaven" is the Chinese word "tian," which means the cosmos or nature. ${ }^{15}$ Therefore, we can think of the pipes of heaven as the various processes of nature. We should also note that "pipings" may be a better translation than "pipes" because it emphasizes the fact that the pipings of heaven

\footnotetext{
${ }_{11}$ Ames and Hall, Daodejing, 14.

12 This phrase comes from Kwang-Sae Lee, East and West: Fusion of Horizons (Paramus, NJ: Homa \& Sekey, 2006).

13 Chuang Tzu, Chuang Tzu: The Inner Chapters, trans. A.C. Graham (Indianapolis/Cambridge, Hackett, 2001), 12.

${ }^{14}$ Chuang Tzu, Wandering on the Way: Early Taoist Tales and Parables of Chuang Tzu, trans. Victor H. Mair (Honolulu, Hawai'i: University of Hawai'i Press, 1994), 49. Note: I have utilized different aspects of two translations of the Chuang $T z u$ to make the point come across more clearly.

${ }^{15}$ For an analysis of the Chinese word "tian," see Hans-Georg Moeller's The Philosophy of the Daodejing (New York: Columbia University Press, 2006), 44. Ames and Hall also provide an explanation in Daodejing, 63-66.

(C) 2013 Casey Rentmeester http://www.kritike.org/journal/issue_12/rentmeester june2013.pdf ISSN 1908-7330 


\section{PERSPECTIVISM NARROW AND WIDE}

are processual events or happenings. ${ }^{16} \mathrm{Just}$ as Nietzsche thought that there is no such thing as a stable "thing," ${ }^{17}$ Chuang Tzu sees phenomena as dynamic processes rather than fixed "things."

Now that we understand the conceptual underpinnings of this passage, we can focus on explicating it. The main point is that the processes of nature all work spontaneously in accordance with the way in which they are constituted. This is what Chuang Tzu seems to mean when he talks of "the natural propensities of the hollows themselves." Each processual entity in nature has a "natural propensity" to flourish as long as it is placed in the proper environment to do so. There is no need for anything over and above each entity to guide it to its fruition. In commenting on this passage, Hans-Georg Moeller states, "who blows the pipe of heaven? The answer is: No one-everything in the world 'ultimately' makes its own sound." ${ }^{18}$ In other words, everything in the world acts as it does spontaneously, without anyone behind the scenes pulling the strings. This spontaneity of natural processes includes the processes that human beings go through. Just as Nietzsche is suspicious of an autonomous subject over and against the world, Chuang Tzu consistently emphasizes that there is no such thing as a substantial subject. Human beings are natural beings, which means that they participate in these spontaneous strivings of energy just as much as any other natural entities. The various spontaneous processes interact with one another to form a harmonious, self-sustaining, ceaselessly novel, balanced whole, which we call nature.

Here, we can already see a major point of divergence between Nietzsche's interpretation of nature and the Daoist interpretation. Both Nietzsche and Chuang Tzu view the natural world in terms of dynamic energies in constant flux, yet the fundamental nature and interaction of these energies differs in each philosophical framework. Whereas the Daoist conception of nature is one of flows of energy that work together to create a harmonious equilibrium, Nietzsche views nature as a battlefield of urges striving to increase their power by overcoming any and all opposing forces, whether they be weak or strong. In other words, whereas Chuang Tzu stresses the interdependence and mutual cooperation of all natural things, Nietzsche stresses the fundamental strife inherent in natural processes that results from each entity working independently to enhance its own power. ${ }^{19}$

${ }^{16}$ Cf. Kwang-Sae Lee, "Two Ways of Perspectivism: Nietzschean and Daoist," in The International Journal of Field-Being (Volume 6, Number 1, 2007), 7.

${ }^{17}$ Cf. Friedrich Nietzsche, Human, All Too Human: A Book for Free Spirits, trans. Marion Faber, with Stephen Lehmann (Lincoln, Nebraska: University of Nebraska Press, 1996), 19.

18 Hans-Georg Moeller, Daoism Explained: From the Dream of the Butterfly to the Fishnet Allegory (Chicago and La Salle, IL: Open Court, 2004), 136.

${ }_{19}$ Perhaps the best passages where Nietzsche attempts to justify the pursuit and overcoming of strife can be found in his short essay, "Homer's Contest," trans. Carol Diethe and ed. Keith Ansell-Pearson in the collection On the Genealogy of Morality and Other Writings (Cambridge: 
The Nietzschean view of reality as strife and the Daoist view of reality as harmonious is most likely a result of their historical and cultural contexts. Nietzsche is a product of the West, which means that his view of reality has been informed primarily from the Greeks and the Germans who came before him. Heraclitus, one of Nietzsche's favorite Greek philosophers, famously stated that "war is the father of all and king of all"20 and Kant, one of the most influential German philosophers, believed that "the natural state is one of war." ${ }^{21}$ Heraclitus and Kant are both emphasizing that strife is a fundamental aspect of nature, and Nietzsche appropriates this view. ${ }^{22}$ Chuang Tzu, on the other hand, has learned from thinkers like Lao Tzu, who stresses the harmonious equilibrium of nature. Throughout the Daodejing, Lao Tzu stresses the harmony of nature, and this comes out most clearly in chapter 16 , which states:

In the process of all things emerging together we can witness their reversion. Things proliferate, and each again returns to its root. Returning to the root is called equilibrium. Now as for equilibrium-this is called returning to the propensity of things. ${ }^{23}$

For Daoist thinkers (as well as Eastern thinkers generally), conflict is usually seen as a temporary deviation from the natural, harmonious flow of things. Harmony is a basic tenet of Eastern thought because Eastern thinkers tend to view nature as an interdependent network of entities. The three major worldviews of the East-Confucianism, Daoism, and Buddhism—all believe that each natural entity needs to work together with other entities in order to function properly.

Cambridge University Press, 2007). Here, looking at the Greeks in particular, Nietzsche claims "the greater and more eminent a Greek man is, the brighter the flame of ambition to erupt from him, consuming everyone who runs with him on the same track" (177). Nietzsche's point in this essay is that overcoming strife is a necessary means in the pursuit of excellence.

${ }^{20}$ Heraclitus, fragment 79, quoted in Readings in Ancient Greek Philosophy: From Thales to Aristotle, Second Edition, ed. S. Marc Cohen, Patricia Curd, and C.D.C. Reeve (Indianapolis, IN: Hackett Publishing Company, Inc., 2000), 32. As an aside, an interesting, but often ignored, note that Heraclitus makes is that strife allows for harmony to happen. In fragment 49 , he is quoted as saying, "What is opposed brings together; the finest harmony is composed of things at variance, and everything comes to be in accordance with strife."

${ }^{21}$ Immanuel Kant, Perpetual Peace, in On History, ed. Lewis White Beck and trans. Lewis White Beck, Robert E. Anchor, and Emil L. Fackenheim (New York: Macmillan Publishing Company, 1963), 92.

22 For the influence of Heraclitus on Nietzsche, see Christopher Cox, Nietzsche: Naturalism and Interpretation (Berkeley and Los Angeles: University of California Press, 1999). For the influence of Kant on Nietzsche, see R. Kevin Hill, Nietzsche's Critiques: The Kantian Foundations of his Thought (Oxford: Oxford University Press, 2003).

${ }^{23}$ Cf. Ames and Hall, Daodejing, 99.

(c) 2013 Casey Rentmeester http://www.kritike.org/journal/issue 12/rentmeester june2013.pdf ISSN 1908-7330 


\section{PERSPECTIVISM NARROW AND WIDE}

Chuang Tzu talks about the interdependence of natural processes by showing how every natural process depends on others and transforms into others. Chapter 18 of the Chuang Tzu speaks of germs that transform into various types of entities depending on their environments. These entities, in turn, transform into different entities according to their surroundings. Eventually, when the conditions are right, a human being will be born of these natural processes, and this human being will transform into something else when it dies. The fundamental point is that "the myriad things all come out from the wellsprings and all reenter the wellsprings." ${ }^{24}$ Nature is a ceaseless flow of dynamic energies that are interdependent-and this interdependence creates a healthy equilibrium.

Instead of stressing the interdependence of things, Nietzsche's idea of the world as will to power is one of strife and conflict. He states, "life itself is essentially appropriation, injury, overpowering of what is alien and weaker; suppression, hardness, imposition of one's own forms, incorporation and at least, at its mildest, exploitation." ${ }^{25}$ Nietzsche makes it clear that he is not positing any nasty value judgments in this particular passage. He urges us not to think of exploitation in a nasty sense, but rather to view it as a fundamental characteristic of reality. The world is fundamentally a conflict-ridden battleground of energies seeking an enhancement of power for Nietzsche, making him at odds with Chuang Tzu's view of the world as a harmonious concatenation of interdependent processes. This fundamental split in their views of reality has important consequences for their prescriptive attitudes regarding how we should live in the world.

\section{Living according to Nature}

Both Nietzsche and Chuang Tzu think that human beings ought to live in accordance with nature, which is more of an Eastern way of thinking than a Western one. A fundamental doctrine of Western thought is the idea that just because the world is structured in a certain way doesn't mean that human beings ought to live according to this structure. For instance, even if human beings are naturally selfish creatures, this does not necessarily mean that humans ought to live selfishly. In fact, it may be deemed unethical to follow one's natural impulses and act selfishly. ${ }^{26}$ The idea that it is fallacious to derive a prescriptive statement from a descriptive statement (i.e., to infer an "ought" from an "is") stems from David Hume, who says that the validity of such an inference is "altogether

\footnotetext{
${ }^{24}$ Chuang Tzu, Wandering on the Way, 173.

${ }^{25}$ Nietzsche, Beyond Good and Evil, 258.

${ }^{26}$ In the Western philosophical tradition, Kant and Thomas Hobbes are clear proponents of this sort of view that one has to curb one's natural tendencies to live an ethical life.
} 
inconceivable" since the statements are entirely different from each other. ${ }^{27}$ While Western philosophers generally try to uphold this is/ought distinction, Eastern thinkers for the most part do not view this distinction as valid and instead think that human beings ought to conform to nature. The most influential thinker of the East, Confucius, believed that the moral order should mirror the natural order, and Eastern thought in general has upheld this view. ${ }^{28}$ In fact, the attempt to separate value statements from factual statements is considered fallacious reasoning in the East. S.C. Chen has called dualistic attempts at keeping the factvalue distinction the "fallacy of bifurcating nature."29 The idea here is that human beings are fundamentally natural creatures, which means that we should view humans as part of the natural order rather than viewing them as outside of it. Since we are natural creatures, we should live according to life's functions rather than try to rise above them or eschew them as "animalistic" or "primitive." 30

In Beyond Good and Evil, Nietzsche ridicules the Stoic maxim that one should live according to nature, ${ }^{31}$ which seems to give credence to the idea that Nietzsche himself eschews naturalism. However, a broader look at the Nietzschean corpus shows that Nietzsche is in fact in favor of living in accordance with nature. His love of the Dionysian aspects of life is one of the ways in which he demonstrates his commitment to naturalism. In his first major work, The Birth of Tragedy, he states, "Under the charm of the Dionysian not only is the union between man and man reaffirmed, but nature which has become alienated, hostile, or subjugated, celebrates once more her reconciliation with her lost son, man."32 One of the aspects of the Dionysian is that it allows human beings to regain their natural continuity with nature and, since Nietzsche calls himself "the last disciple and initiate of the god Dionysus, ${ }^{33}$ it is clear that he praises this continuity of 1888), 469.

27 David Hume, A Treatise of Human Nature, ed. L.A. Selby-Bigge (Oxford: Clarendon,

28 In Sources of Chinese Tradition, the commentators note that "Confucius had a strong belief in a natural order that was also a moral order." Cf. Volume I, ed. Wm. Theodore de Bary, Wing-tsit chan, and Burton Watson (New York: Columbia University Press, 1960), 17. While Confucius himself wasn't explicit with regard to his view on human nature, his follower Mencius clearly believed that humans were naturally good and should embrace this good nature. While Daoists are often at odds with Confucian views, they clearly believe one should follow nature.

29 This insight was provided by Martin Schönfeld. See his essay "The Green Kant" in Environmental Ethics: Readings in Theory and Application, Fifth Edition, ed. Louis P. Pojman and Paul Pojman (Belmont, CA: Thomson, 2008), 55.

30 There are exceptions to this admittedly overly generalized claim. Hsün Tzu, for instance, believed that human beings were naturally evil and required cultivation through education to bend our evil nature in order to attain the status of moral human beings.

${ }^{31}$ Cf. Nietzsche, Beyond Good and Evil, 9.

32 Cf. Friedrich Nietzsche, The Birth of Tragedy, in Basic Writings of Nietzsche, trans. and ed. by Walter Kaufmann (New York: Random House, Inc., 1967), 1.

${ }^{33}$ Nietzsche, Beyond Good and Evil, 295. 
human beings and nature. ${ }^{34}$ One can also see a certain sort of naturalism in Thus Spoke Zarathustra. Nietzsche has Zarathustra repeatedly implore his disciples to remain faithful to the earth, implying that human beings should embrace rather than shun their natural condition..$^{35}$ Moreover, the emphasis he places on selfovercoming and life affirmation (i.e., "saying yes to life") throughout his thought are indicative of his naturalism.

However, most of Nietzsche's indications of naturalism are not straightforward-rather, his naturalistic tendencies often come out when he is engaging in criticism. One of the major reasons he chastises Christianity is because it is not only unnatural but it is anti-nature. In speaking of the way in which Christian virtues have permeated our modern existence, he states, "We modern men are the heirs of the conscience-vivisection and self-torture of millennia... Man has all too long had an 'evil eye' for his natural inclinations, so that they have finally become inseparable from his "bad conscience." ${ }^{\prime 36}$ Walter Kaufmann notes that the German word translated as "self-torture" in this passage is Selbsttierquälerei, which literally means "animal torture." Therefore, Nietzsche is saying that the problem with Christianity is that it "involves a mortification of the animal nature of man." ${ }^{37}$ Nietzsche views Christianity as a fundamentally unhealthy religion because it goes against our natural instincts by not only prohibiting certain natural activities (e.g., engaging in sexual activities, eating certain foods, etc.), but also by imposing an unwarranted sense of guilt for those who engage in such activities.

Instead of trying to overcome our natural instincts, Nietzsche thinks that we should embrace them. And, since his view of reality is one of exploitation, this leads him to endorse exploitative practices in certain instances, especially when such practices are necessary. Since life is essentially a battlefield of urges striving to overcome opposing forces and since human beings are a part of this process, we participate in this battlefield just as much as any other organic being. This is one of

${ }^{34}$ As most commentators point out, Nietzsche's conception of the Dionysian changes throughout his work. Whereas in The Birth of Tragedy the Dionysian is juxtaposed with the Apollonian, in his later thought he seems to conceive of the Dionysian as a synthesis between the Dionysian and Apollonian elements of his early thought. Therefore, in calling himself "the last disciple of Dionysus" in Beyond Good and Evil, he may be thinking of the Dionysian in a slightly different way than he did in The Birth of Tragedy. Since this may be the case, one may be uneasy of my juxtaposing his early conception with the later one. However, since the natural characteristic of Dionysian is constant throughout his thought, I think the juxtaposition of his early and later thought is warranted in this particular instance.

${ }^{35}$ Cf. Friedrich Nietzsche, Thus Spoke Zarathustra, in The Portable Nietzsche, ed. and trans. by Walter Kaufmann (New York: Penguin Books, 1980), 144 and 188.

${ }^{36}$ Nietzsche, On the Genealogy of Morals, 24 (emphasis added).

37 This phrase comes from Walter Kaufmann, footnote 3, page 531 of Nietzsche, On the Genealogy of Morals, 24.

(C) 2013 Casey Rentmeester http://www.kritike.org/journal/issue 12/rentmeester june2013.pdf ISSN 1908-7330 
the reasons as to why he ridicules those who want to get rid of the exploitative aspects of our society. In Beyond Good and Evil, he states:

Everywhere people are now raving... about coming conditions of society in which "the exploitative aspect" will be removed-which sounds to me as if they promised to invent a way of life that would dispense with all organic functions. "Exploitation" does not belong to a corrupt or imperfect and primitive society: it belongs to the essence of what lives, as a basic organic function; it is a consequence of the will to power, which is after all the will to life. ${ }^{38}$

Since exploitation is a basic organic function, there is nothing wrong with human beings exploiting others. In fact, on occasion, Nietzsche argues that human beings ought to exploit others. There are even certain instances in which he blatantly endorses slavery. He states explicitly that "the essential characteristic of a good and healthy aristocracy" is that it "accepts with a good conscience the sacrifice of untold human beings who, for its sake, must be reduced and lowered to incomplete human beings, to slaves, to instruments. ${ }^{.39}$ In order to understand this quote, we will have to gain a better grasp of Nietzsche's view of human beings.

Instead of viewing human beings as fundamentally similar due to their existence in the same species, Nietzsche believes that there are different types of human beings, which means that human beings are not equal. This comes out most clearly when he has Zarathustra state: "I do not wish to be mixed up and confused with these preachers of equality. For, to $m e$ justice speaks thus: 'Men are not equal.' Nor shall they become equal!"40 In other words, not only are human beings naturally unequal, but we should not strive to treat human beings as equal. According to Nietzsche, "there is an order of rank between man and man" ${ }^{\text {"11 }}$ and, while he admits that these rankings are complex, Nietzsche splits them up into "higher" and "lower" types. He praises the higher types of human beings because they embrace their "well-constituted" natures and he disdains the lower types because they are either naturally weak or they have fallen prey to Christian virtues, which are fundamentally against nature. Whereas higher types are distinguished by their excess of power, independence, and intolerance towards those who are weaker, lower types of human beings are described as warm-hearted, patient, humble, and friendly. ${ }^{42}$ Since these lower types of human beings do not exhibit the

\footnotetext{
38 Nietzsche, Beyond Good and Evil, 259.

${ }^{39}$ Ibid., 258.

${ }^{40}$ Nietzsche, Thus Spake Zarathustra, 213.

${ }^{41}$ Nietzsche, Beyond Good and Evil, 228.

42 Ibid., 260-261.
} 
natural instincts of being independent and exploitative, Nietzsche thinks it is not only acceptable to treat them as slaves but sometimes necessary since "every enhancement of the type 'man' ... needs slavery in some sense or other." ${ }^{43}$ Ideally, Nietzsche wants to see a world in which the higher, strong human beings are able to flourish, and this sometimes comes at the expense of the lower types of humans. This explains why he considers the aforementioned aristocratic society that reduces other human beings to slaves as 'good' and 'healthy. ${ }^{44}$

Nietzsche thinks that it is important to be honest about the fact that slavery is required if we want to follow the natural course of things. He states, "Life always lives at the expense of other life'-he who does not grasp this has not taken even the first step toward honesty with himself." ${ }^{45}$ Since he believes that human beings are supposed to live in accordance with nature, he thinks there is nothing wrong with the natural tendency of overpowering the weak to enhance the power of the strong. The fact that overpowering and exploiting opposing forces is natural means that one should participate in these practices without hesitation, and certainly without any sense of guilt attached to such practices. ${ }^{46}$

Like Nietzsche, Chuang Tzu espouses a type of naturalism, yet his view of nature leads him to a much different perspective on how to treat others. One important aspect of Daoism is that human beings should conform to the natural processes in order to attain a healthy, sustainable equilibrium. Chuang Tzu advises us to "follow along with the nature of things and admit no personal preference.

${ }^{43}$ Ibid., 257.

${ }^{44}$ An excellent passage that illustrates the dialectic between the higher and lower types can be found in Nietzsche's Twilight of the Idols Or, How to Philosophize with the Hammer, trans. Richard Polt (Indianapolis and Cambridge: Hackett, 1997), IX, 33. Here, Nietzsche says, "All individuals can be viewed in terms of whether they represent the ascending or the descending line of life." We should point out that higher types in the Nietzschean framework do not necessarily seek out to oppress the lower types. In many cases, they simply go on with their creative lives and ignore the lower types. However, there are cases in which the lower types must be exploited to further the means of the higher types, and Nietzsche embraces this as necessary (not a necessary evil_-just necessary!).

${ }^{45}$ Nietzsche, Will to Power, 369.

46 Perhaps I should qualify what I mean by this notion of overpowering. On my interpretation, Nietzsche clearly endorses the exploitation of the weak by the strong, and this sometimes even includes political subjugation. For instance, consider the full passage in Beyond Good and Evil that I alluded to earlier: "The essential characteristic of a good and healthy aristocracy... is that it experiences itself not as a function (whether of the monarchy or the commonwealth) but as their meaning and highest justification-that it therefore accepts with a good conscience the sacrifice of untold human beings who, for its sake, must be reduced and lowered to incomplete human beings, to slaves, to instruments. Their fundamental faith simply has to be that society must not exist for society's sake but only as the foundation and scaffolding on which a choice type of being is able to raise itself to its higher task and to a higher state of being" (258). For an alternative understanding of what Nietzsche's will to power means in the context of the interaction of forces, see Gilles Deleuze, Nietzsche and Philosophy, trans. by Hugh Tomlinson (New York: Columbia University Press, 1983).

(C) 2013 Casey Rentmeester http://www.kritike.org/journal/issue 12/rentmeester june2013.pdf ISSN 1908-7330 
Then all under heaven will be well governed." ${ }^{37}$ In other words, if we simply allow things to evolve according to their natural propensities, everything will go smoothly. Since nature has a tendency of reaching a stable equilibrium, a person who follows natural processes will also reach a state of balance.

One can see Chuang Tzu's naturalism in his critique of the conservative aspects of his culture. Just as Nietzsche attacks Christianity for being "anti-nature," Chuang Tzu attacks Confucian virtues for being artificial impositions on people. Although Confucius tried to implement a moral order that mirrored nature, Chuang Tzu thinks that the rituals that he advocated were too rigid and soon became ossified. People were performing the Confucian rituals such as humaneness and righteousness merely because they were told that they were right rather than acting humanely and justly because people deserve to be treated as such (which is what Confucius envisioned). Therefore, Chuang Tzu argues against such rituals as being unnatural and contrived. He states:

That which is ultimately correct does not lose the characteristics of its nature and destiny... Thus, although a duck's legs are short, if we extend them it will come to grief; although a crane's legs are long, if we cut them short, it will be tragic. Therefore, if what by nature is long is not cut short, and if what by nature is short is not extended, there will be no grief to dispense with. One suspects that humaneness and righteousness are not attributes of humanity! Otherwise, why would those humane men be so full of grief? ${ }^{48}$

The point here is not that people should refrain from treating others humanely or justly since these virtues are unnatural. Rather, the point is that imposing morality onto people only harms them by forcing them to act insincerely, which thereby fills them with grief. As Thomas Merton points out:

Chuang Tzu is not against virtue (why should he be?), but he sees that mere virtuousness is without meaning and without deep effect either in the life of the individual or in society. Once this is clear, we see that Chuang Tzu's ironic statements about "righteousness" and "ceremonies" are made not in the name of lawless hedonism and

\footnotetext{
${ }^{47}$ Chuang Tzu, Wandering on the Way, 68.
}

48 Ibid., 76. 
antinomianism, but in the name of that genuine virtue which is "beyond virtuousness."

Instead of trying to live up to the Confucian ideals of humaneness and righteousness, people should go "beyond good and evil" (to invoke a Nietzschean idea) and simply act naturally.

The view that natural actions are good actions can be found in the advice that Chuang Tzu provides when he tells people to "get rid of goodness and you will naturally be good." ${ }^{50}$ When Nietzsche speaks of naturally being good, he does so in the context of the higher, noble humans looking at themselves and affirming their superiority and powerfulness above others. ${ }^{51}$ However, when Chuang Tzu speaks of being naturally good, he means it in a quite different way. Being naturally good simply means acting sincerely for Chuang Tzu. When people act in certain ways because that is "what one does" or "what is appropriate" in such situations, one is not necessarily being good. On the other hand, when a person acts sincerely this is truly good since "one's true nature... is the ultimate expression of pure sincerity." ${ }^{2}$ If we take a broad look at the passages in the book of Chuang Tzu, we find that Chuang Tzu is not advising against treating people with humaneness and righteousness; he is simply against acting in these ways simply because conventional morality tells us to do so. One does not need a conventional moral system to treat others with respect; rather, one should do so out of sincerity.

In fact, if one truly understands nature and acts according to it, one will naturally treat others with respect. Since "heaven shows no preference in whom it covers nor earth in whom it supports" 53 and humans are supposed to follow heaven (understood as the processes of nature), human beings are told to do the same. Since everything comes from the wellsprings of nature, no particular thing is privileged, which implies that everything deserves equal respect. There is no legitimate basis for privileging any one being over others since they all contribute to the processes of nature in their own unique way. Therefore, whereas Nietzsche thinks that it is perfectly legitimate for a "noble soul" to think that "other beings must be subordinate by nature and have to sacrifice themselves," ${ }^{54}$ Chuang Tzu thinks that it is natural for people to view other human beings (as well as other natural creatures) as equally important. He states, "Someone who climbs high should not think that he is esteemed; someone who dwells low should not think that he is debased." ${ }^{\text {s }}$ Since we are all natural beings and since nature does not

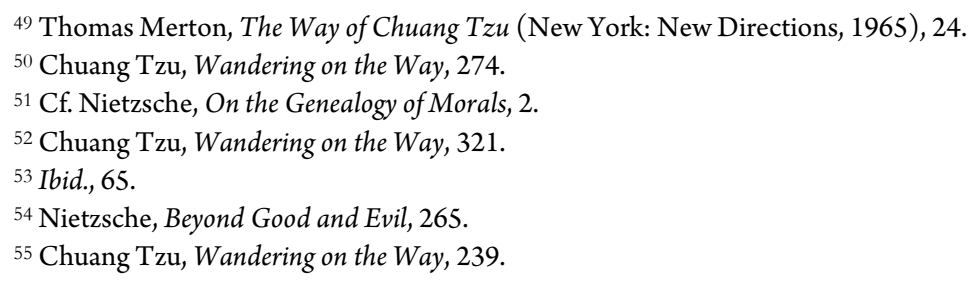


privilege any particular thing over any other, there is no reason to think that one person is better than another. Therefore, even those who are endowed with the "superior" characteristics of the Nietzchean higher type are supposed to respect others. Chuang Tzu advises everyone "not to be caustic towards others, not to be hostile to the masses, [and] to desire peaceful repose for all under heaven so as to preserve the lives of the people." ${ }^{n 6}$ Treating people in this manner will allow for people to flourish in accordance with their natural propensities, and this will ultimately result in a harmonious state of equilibrium.

One of the ways in which Chuang Tzu preaches equality is by showing that everything is useful in its own unique way. This is why he says that "great knowledge... does not belittle what is small nor make much of what is big, knowing that their capacities are limitless. ${ }^{\text {} 57}$ Perhaps the most famous example in the Chuang Tzu that emphasizes this point is the useless tree. ${ }^{58}$ Chuang Tzu speaks of a huge tree that is so awkward, crooked, and knotty that even the most skillful carpenter in the world could not utilize its wood for lumber. Moreover, the tree bears no fruit, so it does not contribute directly to anyone's nourishment. A superficial examination of the tree would find it to be utterly useless. However, it is precisely this uselessness that allowed the tree to grow so large and this in turn allows it to provide shade for the townspeople on sunny days. While there are various ways in which a person can interpret this example, one of the points that Chuang Tzu seems to be making is that even the most seemingly useless things are important because they serve their unique purpose in the greater order of things. Nietzsche once posed the question "What, after all, is 'useful'?" and answered that "One must ask 'useful in relation to what?" ${ }^{99}$ Chuang Tzu agrees with Nietzsche on this point, yet, unlike Nietzsche, he uses it to show that every being deserves equal consideration. In other passages, Chuang Tzu makes the same point in regard to human beings. He speaks of the ugliest person in town as the person whom the people respect the most because he has so much integrity and the crippled man as the person whom half the state follows because he is the wisest. In such examples, Chuang Tzu is trying to make the point that all natural beingsboth human and non-human-contribute to the harmonious functioning of nature and, therefore, everything should be treated with respect.

\section{Implications for Perspectivism}

The radical egalitarianism that Chuang Tzu espouses is intimately intertwined with his espousal of perspectivism, which differs from Nietzschean

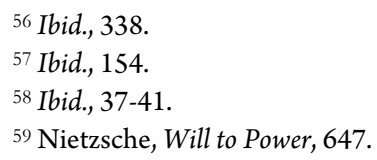


perspectivism. Before we look at Chuang Tzu, let us examine Nietzsche's perspectival outlook. One of the most attractive aspects of Nietzsche's philosophy for readers is his perspectivism, which is the idea that truth can only be understood from a given perspective. Nietzsche states, "There are many kinds of eyes... and consequently there are many kinds of 'truths,' and consequently there is no truth. ${ }^{60}$ Since there is no such thing as truth devoid of a particular perspective, there can be no such thing as "Truth" (i.e., absolute truth). Therefore, no single perspective should be privileged over all others since each and every perspective is limited by its particular framework, which is necessarily biased. There is not a single absolute truth about the world, but many different kinds of truths that each gains its legitimacy from its own perspective. One of the consequences of this view is that disciplines like art and poetry can have just as "true" a view of reality as physics and biology. The poet, artist, and scientist each views reality from a particular perspective and therefore stresses different aspects of reality. However, it is illegitimate to consider one to be "more true" than the others because no one is able to attain a "view from nowhere" wherein one can view reality as it is in itself, completely devoid of biases.

This aspect of Nietzsche's perspectivism is appealing, especially when we consider the current privileging that is granted to the sciences over other disciplines such as the humanities. However, what commonly gets glossed over in regard to Nietzsche's perspectivism is the fact that certain perspectives are illegitimate according to him. Nietzsche consistently privileges the noble perspectives of the "higher types" over those of the lower types of humans. Perspectives that spawn from activity rather than reactivity, that are life-affirming rather than life-denying, and that are powerful rather than weak are granted a superior position by Nietzsche. While he admits that different types of people require different types of values, he constantly privileges the noble, healthy perspectives and disdains what he deems to be decadent. He says that the noble soul "knows itself to be at a height," ${ }^{16}$ implying that it has a more privileged position. And, he consistently aligns himself with this privileged perspective and shuns what he takes to be lower perspectives.

It is clear that Nietzsche realizes that his particular view on life is perspectival (he says that the truths he puts forth are his own and he urges others to posit their own creative viewpoints ${ }^{62}$ ), which shows that he does not take his view of reality to be the absolutely "right" one. In this regard, Nietzsche shows that he takes perspectivism seriously. At the same time, however, in denying the validity of certain perspectives, Nietzsche does not espouse a thoroughly radical perspectivism. In other words, while he grants that all truths are perspectival and

\footnotetext{
${ }^{60}$ Ibid., 540.

${ }^{61}$ Nietzsche, Beyond Good and Evil, 265.

${ }^{62}$ See especially the end of part one of Thus Spake Zarathustra.
} 
therefore limited in their scope (including his own), he does not think that all perspectives deserve to be taken seriously. Chuang Tzu's perspectivism goes further than Nietzsche in this regard because he not only thinks that all truths are perspectival, but he also thinks that this means that no particular perspectives should be unconditionally privileged. This idea stems directly from his egalitarianism. Since everything deserves to be treated with respect, the various perspectives that different beings hold also deserve respect. ${ }^{63}$ In speaking of the dwellings of different creatures, Chuang Tzu argues that different ways of life are right for different types of creatures—and none of these ways is ultimately correct. He states:

How can we know that what I call knowledge is not really ignorance? How can we know that what I call ignorance is not really knowledge?...If people sleep in damp places, they develop lumbago or even partial paralysis. But would the same thing happen if a loach did so? If people dwell in trees, they will tremble with vertigo. But would the same thing happen if a gibbon did so? Of these three, which knows the proper place to dwell? ${ }^{64}$

Chuang Tzu goes on to make the point that the notion of what is beneficial and what is harmful is only intelligible from a certain perspective. Therefore, one should not privilege any particular perspective as better than others. ${ }^{65}$ What is right for one being is not necessarily right for another and, furthermore, thinking that one unequivocally "knows better" than another as to what is "really right" is merely an unwarranted display of hubris.

This is one crucial aspect that comes out in Chuang Tzu's idea of harmonizing with nature. He states:

Whether the alternative voices of disputation are relative to each other or not, they may be harmonized within the framework of nature and allowed to follow their own

${ }_{63}$ One may object and say that this very perspective supporting egalitarianism is an unwarranted assumption, just as Nietzsche's inegalitarianism is an unwarranted assumption, in which case Chuang Tzu's perspectivism wouldn't be more radical than Nietzsche's. However, the fact that Chuang Tzu is open to more perspectives and doesn't explicitly shun any particular perspective, other than those that are narrow and close-minded (see chapter two of Wandering on the Way), means Chuang Tzu's perspectivism is more wide-ranging than Nietzsche's.

${ }^{64}$ Chuang Tzu, Wandering on the Way, 20.

${ }^{65}$ I should point out that I am not arguing that Chuang Tzu escaped a particular perspective on life. What I am arguing is that his emphasis on egalitarianism allows his inclusivistic attitude towards perspectives to flourish. 
effusive elaboration so they may live out their years. What does 'harmonized within the framework of nature' mean? I would say, 'Right may not be right, so may not be so. ${ }^{66}$

In other words, different viewpoints are able to coexist within each other to produce a harmony according to Chuang Tzu. However, implicit in this assumption is the idea that oppressive practices cannot be tolerated because such activities undermine both his ideas of egalitarianism and perspectivism. Each perspective is given equal weight as long as it does not inherently undermine the perspectives and ways of lives of others. Therefore, any sort of racist or sexist perspective must be eschewed because such views automatically cut off the voices of others.

We can see a major point of divergence here between Chuang Tzu and Nietzsche. Nietzsche's perspectivism is permissive of oppressive worldviews, while Chuang Tzu thinks that they must be shunned. In Beyond Good and Evil, Nietzsche sets forth some of his truths on woman. Among these truths is his idea that "[man] must conceive of woman as a possession, as property that can be locked, as something predestined for service and achieving her perfection in that." ${ }^{67}$ The best way for a man to view a woman is to view her as his property. Since women are the "weaker sex," ${ }^{18}$ men are supposed to view women as beneath them. Instead of arguing against these self-evidently ludicrous claims, I think what is important to note for our purposes is that Nietzsche's view of women is completely consistent with his version of perspectivism. He is allowed to set forth his truths on women, no matter how oppressive they are, as long as he adds the caveat that his truths on woman are "after all only— $m y$ [i.e., Nietzsche's] truths." ${ }^{\prime 69}$ The problem with allowing such views to proliferate is that it cuts off the viewpoints of women themselves. If women are conceived as merely possessions that can be locked, how can we take the viewpoints of women seriously? As contemporary readers of Nietzsche, we often simply gloss over his sexist passages and try to keep in mind that his relations with women in his personal life were always difficult. However, we seldom note that these sexist claims are consistent with Nietzsche's perspectivism. Therefore, those of us who want to fight for equality for historically oppressed groups such as women may want to turn to Chuang Tzu for a more inclusive (or, exclusive, depending on your focus) form of perspectivism. The fact that Chuang Tzu's perspectivism denies oppressive frameworks makes his philosophy more fruitful for those of us who want to fight for equality.

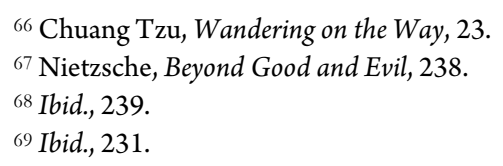




\section{Concluding Remarks}

I have tried to show the ways in which Chuang Tzu's naturalism leads him to a worldview that is more egalitarian than Nietzsche's counterpart. My hope is that this juxtaposition of Nietzsche and Chuang Tzu will give Western liberalminded intellectuals a new philosophical perspective to support their beliefs in equality and perspectivism. Western liberals such as myself like to utilize Nietzsche's idea of perspectivism to argue against oppression, but we are often disappointed in Nietzsche's refusal to consider victimized viewpoints to be legitimate. Chuang Tzu's thinking may provide another perspective to bolster our belief systems. And, since Chuang Tzu's thought shares so much affinity with Nietzsche's, those of us who enjoy reading Nietzsche will most likely find enjoyment in reading Chuang Tzu as well. ${ }^{70}$

Department of Philosophy, Finlandia University, United States

\section{References}

Chuang Tzu, Chuang Tzu: The Inner Chapters, trans. by A.C. Graham (Indianapolis/Cambridge, Hackett, 2001). ,Wandering on the Way: Early Taoist Tales and Parables of Chuang $T z u$, trans. by Victor H. Mair (Honolulu, Hawai'i: University of Hawai'i Press, 1994).

Cox, Christopher, Nietzsche: Naturalism and Interpretation (Berkeley and Los Angeles: University of California Press, 1999).

de Bary, Wm. Theodore et. al., Sources of Chinese Tradition, Volume I, ed. Wm. Theodore de Bary, Wing-tsit chan, and Burton Watson (New York: Columbia University Press, 1960).

Deleuze, Gilles, Nietzsche and Philosophy, trans. by Hugh Tomlinson (New York: Columbia University Press, 1983).

Heraclitus, Readings in Ancient Greek Philosophy: From Thales to Aristotle, Second Edition, ed. S. Marc Cohen, Patricia Curd, and C.D.C. Reeve (Indianapolis, IN: Hackett, 2000).

Hill, R. Kevin, Nietzsche's Critiques: The Kantian Foundations of his Thought (Oxford: Oxford University Press, 2003).

${ }^{70}$ Graham Parkes, an eminent scholar in both Nietzsche and Eastern philosophy, notes that "anyone familiar with Thus Spoke Zarathustra in particular will feel quite at home navigating through the complexities of the Zhuangzi [i.e., the Chuang Tzu]." Cf. Graham Parkes, "Nietzsche and East Asian thought," in The Cambridge Companion to Nietzsche, ed. Bernd Magnus and Kathleen M. Higgins (New York: Cambridge University Press, 1996), 358.

(C) 2013 Casey Rentmeester http://www.kritike.org/journal/issue_12/rentmeester june2013.pdf ISSN 1908-7330 
Hume, David, A Treatise of Human Nature, ed. L.A. Selby-Bigge (Oxford: Clarendon, 1888).

Kant, Immanuel, Perpetual Peace, in On History, ed. Lewis White Beck and trans. by Lewis White Beck, Robert E. Anchor, and Emil L. Fackenheim (New York: Macmillan Publishing Company, 1963).

Lao Tzu, Daodejing: "Making This Life Significant": A Philosophical Translation, trans. by Roger Ames and David Hall (New York: Ballantine Books, 2003).

Lee, Kwang-Sae, East and West: Fusion of Horizons (Paramus, NJ: Homa \& Sekey, 2006).

"Two Ways of Perspectivism: Nietzschean and Daoist," in The International Journal of Field-Being (Volume 6, Number 1, 2007).

Merton, Thomas, The Way of Chuang Tzu (New York: New Directions, 1965).

Moeller, Hans-Georg, Daoism Explained: From the Dream of the Butterfly to the Fishnet Allegory (Chicago and La Salle, IL: Open Court, 2004).

, The Philosophy of the Daodejing (New York: Columbia University Press, 2006).

Nietzsche, Friedrich, Beyond Good and Evil: Prelude to a Philosophy of the Future, trans. by Walter Kaufmann (New York: Random House, Inc., 1966).

, Friedrich Nietzsche: Sämtliche Werke, Kritische Studienausgabe, ed. Giorgio Colli and Mazzino Montinari (Berlin and New York: de Gruyter, 1967-1977), volume 11.

, "Homer's Contest," trans. by Carol Diethe and ed. Keith AnsellPearson, On the Genealogy of Morality and Other Writings (Cambridge: Cambridge University Press, 2007).

, Human, All Too Human: A Book for Free Spirits, trans. by Marion Faber, with Stephen Lehmann (Lincoln, Nebraska: University of Nebraska Press, 1996).

, On the Geneology of Morals, in Basic Writings of Nietzsche, trans. by and ed. Walter Kaufmann (New York: Random House, Inc., 1967). , The Birth of Tragedy, in Basic Writings of Nietzsche, trans. by and ed. Walter Kaufmann (New York: Random House, Inc., 1967).

, The Will to Power, trans. by Walter Kaufmann and R.J. Hollingdale and ed. Walter Kaufmann (New York: Random House, Inc., 1967).

, Thus Spoke Zarathustra, in The Portable Nietzsche, ed. and trans. by Walter Kaufmann (New York: Penguin Books, 1980).

, Twilight of the Idols Or, How to Philosophize with the Hammer, trans. by Richard Polt (Indianapolis and Cambridge: Hackett, 1997). 


\section{RENTMEESTER 21}

Parkes, Graham, "Nietzsche and East Asian thought," in The Cambridge Companion to Nietzsche, ed. Bernd Magnus and Kathleen M. Higgins (New York: Cambridge University Press, 1996).

Schönfeld, Martin, "The Green Kant," Environmental Ethics: Readings in Theory and Application, Fifth Edition, ed. Louis P. Pojman and Paul Pojman (Belmont, CA: Thomson, 2008).

Sellars, Wilfrid, Science, Perception and Reality (London: Routledge \& Kegan Paul Ltd., 1963). 